УДК 34.096

\title{
ПРАВОВОЕ ОБЕСПЕЧЕНИЕ ТРАНСПОРТНОЙ БЕЗОПАСНОСТИ
}

\section{Марков Владимир Петрович}

д.ю.н., доцент

ФГБОУ ВО «Самарский государственный экономический университет»

Аннотация: Автор обращает внимание на проблематику правового обеспечения транспортной безопасности. Существующее в стране правовое обеспечение во многом тормозит решение проблем, как для потребителей транспортных услуг, так и определяет проблемы и риски для существования самой отрасли в контексте пандемии COVID-19. Проанализированы нормы действующего законодательства о транспортной безопасности.

Ключевые слова: безопасность, транспорт, правовое обеспечение, COVID-19.

\section{LEGAL SUPPORT OF TRANSPORTATION SECURITY}

\section{Markov Vladimir Petrovich}

\begin{abstract}
The author draws attention to the problems of legal provision of transport security. The existing legal framework in the country largely impedes the solution of problems, both for consumers of transport services, and determines the problems and risks for the existence of the industry itself in the context of the COVID-19 pandemic. The norms of the current legislation on transport safety have been analyzed.
\end{abstract}

Key words: security, transport, legal support, COVID-19.

Актуальность. Нормальное функционирование транспортной отрасли и инфраструктуры поддержки транспорта, а также их развитие нуждается в организационном обеспечении жизнедеятельности. Важнейшей составляющей организации функционирования отрасли транспорта является правовое обеспечение. В Российской Федерации для этих целей предусмотрено исполнение целого ряда законодательных и нормативных актов, регламентирующих и регулирующих отношения в этой сфере (федеральное законодательство РФ, указы Президента РФ, Постановления Правительства РФ, 
Приказы Минтранса и Росморречфлота). Кроме того, нормативно-правовые акты различного правового уровня определяют наличие правил и предписаний (законы и нормативно-правовые акты органов законодательной и исполнительной власти, ведомственные нормативно-правовые акты).

Целый ряд исследований позволяет констатировать, что существующая нормативно-правовая база характеризуется как фрагментарная, несогласованная и порождает немало противоречий правоприменительной практики $[1 ; 6]$. Целый ряд угроз безопасности (коронавирус, транспортные аварии, терроризм), которые не удалось предоставить, определяет запрос общества и государства на корректировку правовой системы транспортной безопасности. В определенных ситуациях правовые нормы создают препятствия для перемещения людей и грузов, служб обеспечения транспорта и экипажей. Главная здесь проблема заключается в том, что обеспечение транспортной безопасности является сферой компетенции целого ряда субъектов транспортной отрасли (Минтранс России, МВД России, Ространснадзор, Росавиация, Росжелдор, Росморречфлот и др.). Значительное количество нормативно-правовых актов не позволяет точно определить ответственность каждого из субъектов за транспортную безопасность. Следует учитывать, что отрасль транспорта включает в себя коммуникации, инфраструктуру, а потом уже транспорт.

Пандемия covid-19 определила такой риск нарушений транспортной безопасности как передача инфекции в транспорте. До сих пор корне проблема защиты пассажиров не решена. Анализ экономических последствий пандемии показал, что в 2020 г. потери российских транспортных компаний составил 230 млрд. руб. Закрытие границ способствовало тому, что большинство отраслей транспорта терпело рекордные убытки [2]. Эпидемия оказала влияние на транспортные привычки. Государство по примеру мирового сообщества вынуждено было отреагировать и ввести законодательные ограничения по передвижению транспорта в период пандемии [7]. Снятие правовых ограничений в апреле 2020 г. на возобновление транспортной активности позволило нарастить объемы транспортных услуг. Однако, ожидаемая вторая волна эпидемии вынуждает принимать новые правовые меры для обеспечения безопасности. короновирус определяет новые угрозы для безопасности транспортной отрасли. К примеру, ведется поиск новых способов работы транспорта для сокращения физических контактов людей. Правовое обеспечение не учитывает того, что переход на удалённую работу, цифровая 
коммерция может определить снижение спроса на транспортные услуги, определить угрозу экономической безопасности транспортной отрасли [8]. Эти и другие проблемы ставят много вопросов об эффективности законодательных основ вневедомственного государственного контроля за безопасностью в транспортной отрасли.

В рамках данной публикации основной целью статьи является выявление современных тенденций и особенностей правового обеспечения транспортной безопасности в Российской Федерации.

Методика. Существующие проблемы правового обеспечения транспортной безопасности необходимо решать оперативно, так как нерешённость вопросов будет негативно сказываться на экономической эффективности отраслей экономики. Большинство рисков и угроз отмеченного в статье вида безопасности не в полной мере охватывается правовым обеспечением. Проанализированы положения федерального законодательства, нормативно-правовых актов. Исследованы точки зрения различных ученых по указанной проблеме. Проанализированы отдельные материалы отраслевых сайтов и справочных правовых систем.

Основное изложение материала. Обращение к нормам действующего законодательства РФ и анализ точек зрения различных авторов позволяет отметить широкое проблемное поле в контексте правового обеспечения транспортной безопасности.

Важнейшей законодательной основой обеспечения транспортной безопасности является Конституция РФ. Ее нормы не должны вступать в противоречие с другими федеральными законами и нормативно-правовыми актами. В частности нормы о законности, об обеспечении прав и свобод граждан, охраны собственности и общественного порядка. Государство обязуется защищать права и свободы граждан. При этом уточняется, что осуществление прав и свобод граждан не должно нарушать права и свободы других лиц. Конституция РФ при этом уточняет, что права и свободы граждан могут ограничиваться с целью защиты положений данного документа.

Основополагающими для обеспечения транспортной безопасности являются административные, уголовные, уголовно-процессуальные нормативно-правовые акты.

Так, Кодекс РФ об административных правонарушениях (ред. 11.08.2020) определяет типологию материальных признаков правонарушений, на работу с которыми ориентирована деятельность субъектов транспортной безопасности. 
В частности Главы 2 и 3 КоАП устанавливает меры административной ответственности и административного наказания граждан и субъектов за выявленные нарушения в сфере транспортной безопасности. Раздел 2 «Особенная часть» устанавливает особенности административной ответственности граждан за нарушение требований транспортной безопасности, определяющих их конституционные права. При этом особенное место занимает Глава 11 КоАП, определяющая специфику административной ответственности за совершение правонарушений в транспортной сфере (пункты 11.1-11.33).

Материальные признаки преступлений, на определение и предупреждение которых направлены полномочия субъектов транспортной безопасности находят отражение в Уголовном кодексе РФ (ред. 31.07.2020) . В частности Глава 27 устанавливает особенности уголовной ответственности за преступления, свершенные против безопасности и эксплуатации транспорта (статьи 263-271.1). Также следует учитывать, что особенная часть документа также учитывает уголовную ответственность за преступления против общественной безопасности, против экологии, мира и безопасности человечества, преступления против военной службы.

Особенности уголовного судопроизводства за преступления, совершенные в сфере транспорта находят отражение в Уголовнопроцессуальном кодексе РФ (ред. 31.07.2020). Закон определяет основные правовые процедуры уголовного судопроизводства. Кроме того, статья 151 УПК определяет сферы компетенции следователей. В частности, уточняется, что угон воздушного судна или водного транспорта, железнодорожного подвижного состава и др., (около 20 составов преступлений) является сферой компетенции следователей органов ФСБ [5]. В отдельных исследованиях констатируется проблема разграничения подследственности и территориальной несогласованности [8]. Следует признать, в подобных условиях непросто обеспечивать транспортную безопасность.

Вневедомственный контроль со стороны государства за транспортной безопасностью транспорта обеспечивается органами прокуратуры РФ. Нормы статьи 1 Федерального закона №2202-1 «О прокуратуре Российской Федерации» определяют полномочия данного органа, необходимые для организации и активизации межведомственного взаимодействия других органов исполнительной власти, усилия которых необходимы для обеспечения транспортной безопасности. Прокуратура осуществляет надзор за соблюдением прав и свобод человека и гражданина. 
Непосредственно вопросам организации транспортной безопасности посвящены нормы Федерального закона «О транспортной безопасности» №16Ф3 (ред. от 2.12.2019). В документе законодатель определяет основные направления повышения уровня транспортной безопасности, необходимость государственного вневедомственного контроля за данной деятельностью. Немало вопросов в данном законе вызывает положения статьи 5 этого закона, определяющего необходимость оценки уязвимости объектов транспортной инфраструктуры. Данная услуга является платной и предоставляется уполномоченными организациями на основе тарифов и публичного договора с Федеральной службой по тарифам. Ущербность таких экономических отношений очевидна, и взывает немало споров [3]. Хозяйственным субъектам навязывается государством услуга, которая является обязательной. Более того, законодатель возлагает обязанности по обеспечению транспортной безопасности на хозяйствующего субъекта (финансирование затрат на техническое оборудование и средства обеспечения транспортной безопасности и проектирование и реализация планов по транспортной безопасности, включая обучение персонала).

Нельзя обойти стороной и целый ряд Указов Президента РФ.

Указ Президента Российской Федерации № 403 «О создании комплексной системы обеспечения безопасности населения на транспорте». Безусловно, ориентация органов власти на взаимодействие с общественностью должна восприниматься как важнейший организационный принцип.

Постановление Правительства Российской Федерации № 940 «Об уровнях безопасности объектов транспортной инфраструктуры и транспортных средств и о порядке их объявления (установления). Отдельные объекты транспортной инфраструктуры нуждаются в обеспечении повышенных мер безопасности, на что указывает нормативно-правовой акт.

Приказ Минтранса РФ № 34 «Об утверждении Порядка разработки планов обеспечения транспортной безопасности объектов транспортной инфраструктуры и транспортных средств».

Приказ Минтранса РФ № 52, ФСБ РФ № 112, МВД РФ № 134 «Об утверждении Перечня потенциальных угроз совершения актов незаконного вмешательства в деятельность объектов транспортной инфраструктуры и транспортных средств». Последние два акта определяют важность и обязательность межведомственного взаимодействия и предоставления необходимых сведений об объектах транспортной инфраструктуры, определяется регламент. 
Выводы. Подведение итогов статьи позволяет констатировать, что существующее правовое обеспечение транспортной безопасности вызывает немало вопросов у теоретиков и практиков, специализирующихся на данной проблематике. Нормы различных отраслей права регулируют взаимодействие государственных органов в процессе обеспечения транспортной безопасности, однако, межведомственное взаимодействие не всегда проходит четко и без дублирования полномочий. Законодателем определены полномочия органов, определяющих порядок и особенности вневедомственного контроля за обеспечением транспортной безопасности, установлены правовые основания для привлечения к ответственности за нарушение норм транспортной безопасности. Попытка переложить решение вопросов транспортной безопасности на плечи граждан и хозяйствующих субъектов вызывает немало споров и противоречий о том, кто этим должен заниматься. Пока эти вопросы решаются медленно, появляются новые риски и угрозы для граждан, пользующихся транспортом, и для устойчивого развития транспортной отрасли. Пандемия короновируса показала, что в таких условиях правовое обеспечение несовершенно и требует оперативных корректировок.

\section{Список литературы}

1. Дмитриев С.Н. Проблемы правового регулирования транспортной безопасности / С.Н. Дмитриев // Транспорт Российской Федерации. Журнал о науке, практике, экономике. - 2014. - №2(51). - С.34-39.

2. Махмутов Т.А. Как короновирус меняет транспортную сферу: закрытие границ и миллиардные финансовые потери / Т.А. Махмутов // Счетная палата Российской Федерации. - [Электронный ресурс]. - Режим доступа: https://ach.gov.ru (дата обращения: 8.10.2020).

3. Напханенко И.П., Федоров А.В., Донченко Е.Г. Правовое обеспечение транспортной безопасности на объектах транспортной инфраструктуры и транспортных средствах / А.В. Федоров, Е.Г. Донченко [ред. Напханенко И.П.] / Учебное пособие. - М.: Юрайт, 2020. - 83с.

4. Пищелко А.В. Организационно-правовые основы транспортной безопасности в России / А.В. Пищелко // Трансопрное право и безопасность. 2018. - №1. - 189-195.

5. Статья 151. Подследственность. Комментарий к Статье 151 Уголовнопроцессуального кодекса / Уголовно-процессуальный кодекс России 2020. [Электронный ресурс]. - Режим доступа: Источник: http://upkod.ru/chast2/razdel-8/glava-21/st-151-upk-rf (дата обращения: 8.10.2020). 
6. Статья 151. Подследственность. Комментарий к Статье 151 Уголовнопроцессуального кодекса / Уголовно-процессуальный кодекс России 2020. [Электронный ресурс]. - Режим доступа: Источник: http://upkod.ru/chast2/razdel-8/glava-21/st-151-upk-rf (дата обращения: 8.10.2020).

7. Справочная информация: "Коронавирус (COVID-19). Ограничения передвижения и пропускной режим в субъектах Российской Федерации" // СПС Консультант. - [Электронный ресурс]. - Режим доступа: http://www.consultant.ru/document/cons_doc_LAW_351205/ (дата обращения: 8.10.2020).

8. Тетерюк А.Г. Разграничение подследственности между органами внутренних дел на транспорте и территориальными органами внутренних дел, территориальная несогласованность / А.Г. Тетерюк // Юридическая наука и практика: Вестник Нижегородской академии МВД России. - 2015. - №2. C.105-109.

9. Транспортная сфера в контексте COVID-19 / Дайджест. - М.: Счетная палата Российской Федерации, 2020. - 54c. 